\title{
木造根太床の鉛直振動特性に関する実験的研究 EXPERIMENTAL STUDY ON VERTICAL DYNAMIC CHARACTERISTICS OF LIGHT FRAME JOIST FLOOR
}

\author{
鈴木秀三*, 井原行孝**, 藤野栄一*** \\ Shuzo SUZUKI, Yukitaka IHARA and Eiichi FUJINO
}

\begin{abstract}
Impact hammer tests were conducted to demonstrate the vertical dynamic characteristics of light frame joist floor and effect of human load on it. The specimen was 3.64m-long-span and 4.55m-wide joist floor consisted of eleven 2 " by 8 " dimension lumbers and $15 \mathrm{~mm}$-thick plywood subfloor. Furniture and/or human (in four types of posture, respectively) loads were applied to investigate the influence on natural frequencies and damping factors.

The test results indicate, i) Human-load hardly affects natural frequencies,ii) The value of damping factor increases with the body area in contact with the floor,iii) The first natural frequency of joist floor is roughly estimated according to the theory of free vibration equation of motion for bending beam.
\end{abstract}

\section{Keywords : Light-frame joist floor, Natural frequency, Damping factor, Human-load 木造根太床，固有振動数，減衰定数，人間荷重}

\section{1.はじめに}

枠組壁工法による床組や軸組工法における根太を省略した床組 は, 並列材による比較的大きなスパンの床を構成するものであり, 日本建築学会木質構造設計規準 ${ }^{1)}$ が想定している根太床・梁床・組 床の分類の範疇にないように思われる。すなわち, 同規準の「曲げ 材の所要剛性」においては, 「通常の梁」については「初期変形に おける最大たわみがスパンの 1/300 以下かつ，振動障害のないこと」 と規定しているものの, 「床板・根太の類」には振動障害の規定が ないのが現状であり, 今後, 比較的大きなスパンの根太床の振動特 性を考慮した設計法を整備することが必要であると思われる。

筆者等は，鋁直振動性能評価において指標とされる固有振動数・ 減衰定数・振動振幅の観点から, 木造梁床及び木質八イブリッド床

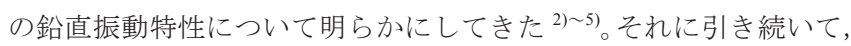
並列材による実大木造根太床の鉛直振動特性について一連の研究を 続けてきていた ${ }^{6) ~ 13)}$

本論文は，並列材を用いた木造実大無開口床組の基本的な鉛直振 動特性を調べるために行った実験の結果をまとめたものであり, 主 として次の 3 点について考察するものである。

1). 並列材・構造用合板で構成された根太床の基本的な静的特性 (ツ 一ウェイ・アクション効果) および固有振動数・減衰定数・モード
形等の振動特性を実験的に明らかにするとともに, 根太床の 1 次固 有振動数の概算方法について検討する。

2)，木造床の減衰性能に及ぼす人間荷重の影響については既に多く の報告があるが例えば14) 17)，人間の姿勢が及ぼす影響についての知見 が少ないことに鑑み，根太床の減衰に及ぼす 4 種類の姿勢について 実験を行い，その影響度合を定量的に検討する。

3). 実物実験に依らず，いわゆる数值実験の可能性を探るために, 実験対象根太床に関して有限要素法解析を行い，実験結果と照合す ることによりその適応性について検証する。

なお，この論文の内容の一部については速報的に日本建築学会大 会学術講演会において報告している ${ }^{10), 11)}$

\section{2. 試験体}

試験体は図 1 のようなスパン $3.64 \mathrm{~m}$, 幅 $4.55 \mathrm{~m}$ の枠組壁工法によ る根太床組で, 図 2 に示寸ように 11 本の床根太【枠組壁工法構造用 製材 : 寸法型式 208, 配置間隔@ $0455 \mathrm{~mm}$ ，曲げ剛性 $\mathrm{EI}=1.79 \sim 1.92$ (実 験による平均值) $2.07 \times 10^{11}\left(\mathrm{~N} \cdot \mathrm{m} \mathrm{mII}^{2}\right)$ 】 と端根太・端根太ころび止め 等で構成された床枠組に, 本実加工針葉樹構造用合板【厚さ $15 \mathrm{~mm}$, 曲げ剛性 $\mathrm{EI}=2.33 \times 10^{9} \quad\left(\mathrm{~N} ・ \mathrm{mIII}^{2}\right)$ （実験による平均值）】をちどりに配 置したものである。床根太材は，端から実測曲げ剛性の順に配置す
* 職業能力開発総合大学校建築システム工学科 教授・工博

** 秋田職業訓練支援センター 職業訓練指導員・修士 (工学)

$* * *$ 職業能力開発総合大学校建築専攻 准教授・博士 (工学)
Prof., Dept. of Architectural Engineering, The Polytechnic University, Dr. Eng. Instructor, Akita Vocational Training Center, M. Eng.

Assoc. Prof., Dept. of Architecture, The Polytechnic University, Dr. Eng. 


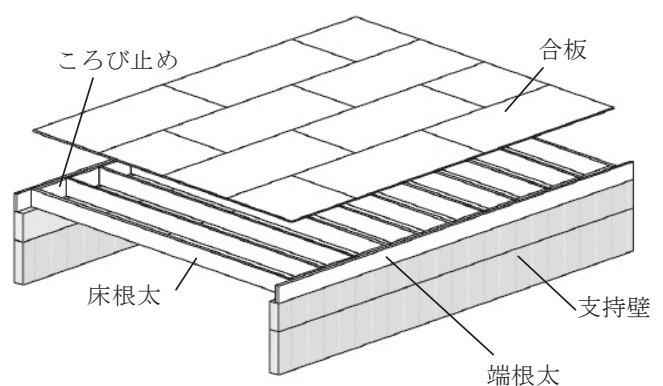

図 1 試験体概要

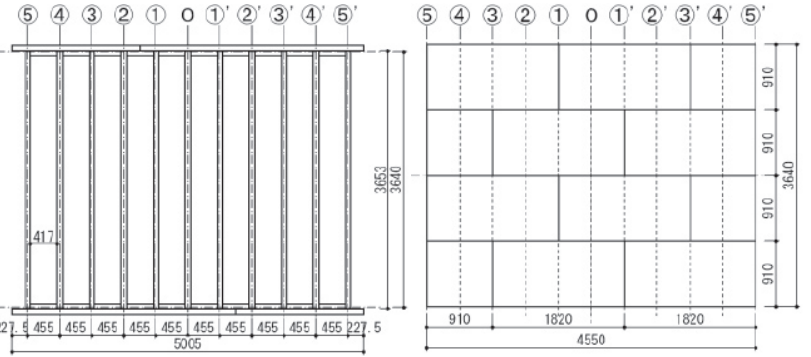

図 2 床組平面図

表 1 床組構成部材一覧表

\begin{tabular}{|c|c|}
\hline $\begin{aligned} & \text { 床根太 } \\
& \text { 端根太 } \\
& \text { ころび止め }\end{aligned}$ & $\begin{array}{l}\text { 枠組壁工法構造用製材（SPF 材 } 2 \text { 級） } \\
\text { 寸法型式（断面 : } 38 \mathrm{~mm} \times 184 \mathrm{~mm}) \\
\text { 曲げ剛性 : } 1.79 \times 10^{11} \mathrm{~N} \cdot \mathrm{mm}^{2} \sim 2.07 \times 10^{11} \mathrm{~N} \cdot \mathrm{mm}^{2}\end{array}$ \\
\hline 床下張り & $\begin{array}{l}\text { 本実加工 }(\mathrm{T} \& \mathrm{G}) \text { 針葉樹構造用合板 } 2 \text { 級 } \\
\text { 寸法 : } 910 \mathrm{~mm} \times 1820 \mathrm{~mm} \quad \text { 厚さ: } 15 \mathrm{~mm} \\
\text { 曲げ剛性 : } 2.33 \times 10^{9} \mathrm{~N} \cdot \mathrm{mm}^{2} \text { (平均值) }\end{array}$ \\
\hline
\end{tabular}

表 2 構成部材間の接合方法一覧表

\begin{tabular}{|l|l|}
\hline 床根太と端根太 & 3 本の CN90 相当のビス 小口打ち \\
\hline 端根太ところび止め & 4 本の CN75 相当のビス 平打ち \\
\hline 頭つなぎと端根太 & 3 本の CN90 相当のビス 小口打ち \\
\hline 構造用合板と床枠組 & CN65 相当のビス外周部@150・中間部@200 \\
\hline 頭つなぎと支持壁 & 床根太間に 3 本の CN90 相当のビス平打ち \\
\hline
\end{tabular}

ることを原則としたので, 床組中央部付近の床根太材が曲げ剛性の 平均値をもつ床根太材となっている。根太床の総質量は $319 \mathrm{~kg}$, 単 位床面積質量は $19.3 \mathrm{~kg} / \mathrm{m}^{2}$ である。床組構成材の諸元及び接合方法 については，表 1 及び表 2 にそれぞれ示すとおりで，各材間の接合 については, 作業の段取りを考慮して, 釘に代えて各釷径に対応す るビスを使用しているところに特徵がある。床組は床根太両端部位 置（2列）で支えているが, 集成材による架台と床組端部との納ま りは図 3 に示したとおりである。実際の建物の床は幅方向端も支持 （4 辺支持）されているのが通例であるが, 本試験体は幅方向が長 い( $4.55 \mathrm{~m}$ 超)根太床を幅 $4.55 \mathrm{~m}$ で切取った状態を想定したものであ るといえる（同スパン $3.64 \mathrm{~m}$ で幅を $2.73 \mathrm{~m}$ まで変化させた場合の振 動特性及び支持条件の影響についての実験も行ったが, 振動特性に 及ぼす幅／スパン比と支持条件等の影響については, 別途報告する 予定である)。

\section{3. 試験方法}

実大根太床を対象とした実験は, ツーウェイ・アクション効果を 調べるための静的鉛直荷重載荷実験, 固有振動数等の基本振動特性 を調べるための実験, 人間荷重が固有振動数・減衰に及ぼす影響を 調べるための実験の 3 種類に大別される。

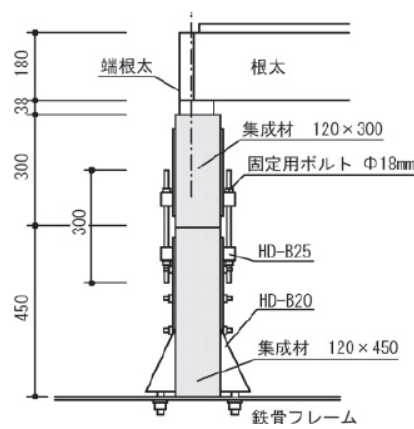

図 3 支持壁と床組の納まり

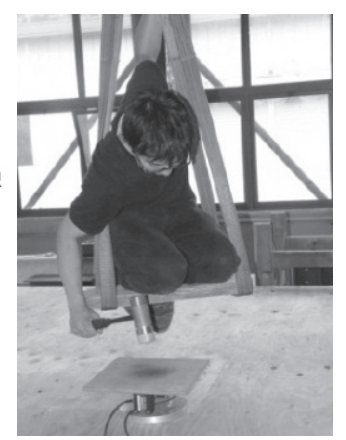

写真 1 加振方法の様子

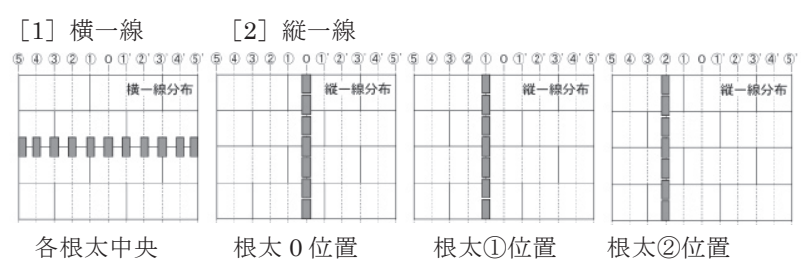

各根太中央

根太 0 位置

根太(1)位置

根太(2)位置

図 4 鉛直荷重載荷の種類

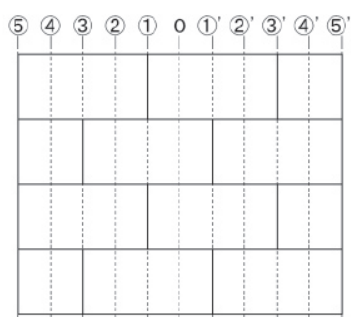

(1) : 固定荷重のみ

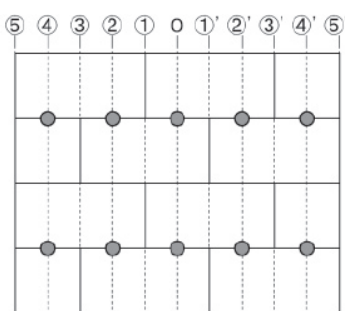

(2) （5)：(1) +人間荷重

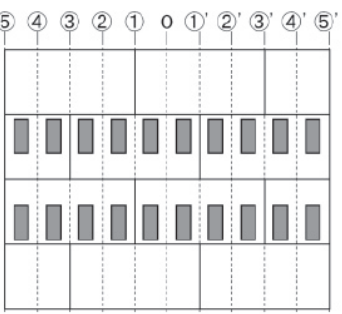

(6) : (1) +物品荷重

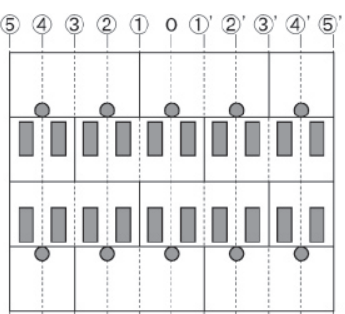

(7) : (1) +物品荷重+人間荷重
図 5 振動試験の試験種類【口は錘、は人間】

\section{1 静的鉛直荷重載荷実験}

並列材による根太床の各根太の鉛直方向変位については, ツーウ エイ・アクション効果の影響を受けることが知られており，その効 果は床を構成する床根太の配置間隔・曲渆性及び床下張り材の曲 げ剛性の組み合わせによって決まると考えられている ${ }^{1)} 。$ 本論文で は, 実験対象とした実大床根太のツーウェイ・アクション効果を含 めた基本的特性を調べておくために静的鉛直荷重載荷実験を行っ た。鉛直荷重載荷は, 図 4 に示寸ように[1]横一線分布荷重載荷 : 床 組のスパン中央位置横一線の各床根太位置に鍾により集中荷重 $755 \mathrm{~N} / \mathrm{m}$ (合計重量 $2747 \mathrm{~N}$ ) を加える方法と, [2]縦一線分布荷重載荷 : 根太床中央部付近の任意の根太材 1 本（０，(1)または(2)）に，錘によ り分布荷重 $752 \mathrm{~N} / \mathrm{m}$ （合計重量 3421N）を加える方法とにより行い, 全根太材のスパン中央部の鉛直変位を電気式変位計 (精度 $1 / 200 \mathrm{~mm}$ ) により計測した。

\section{2 基本振動特性実験}

固有振動数等の基本振動特性を調べるための実験として，インパ クトハンマー加振実験を行った。この場合, 床の固有振動数を変化 
させるために, 固定荷重だけの場合 (図 51)参照 : ○数字は表 3 に対 応) と物品荷重として錘 20 個 (平均質量 $25.6 \mathrm{~kg} /$ 個, 合計 $513 \mathrm{~kg}$ ) を 分散的に付加した場合 (図 56)参照)の 2 条件について実験を行った。 加振は床組中央位置とし, 人間荷重の影響を避けるためにブラン コに乗った実験者が, ロードセルを介してインパクトハンマー加振 を加えることとした(写真 1 参照)。各部分の加速度は, 図 6 の a1〜 a18の位置に取り付けた圧電型加速度計により測定し, 変位につい ては各床根太のスパン中央（図 6 の a1〜a11）の下面に取り付けた 電気式変位計（精度 $1 / 200 \mathrm{~mm}$ ）により測定した。得られたアナログ 信号は $\mathrm{A} / \mathrm{D}$ 変換後, 入力をインパクトハンマーの加振力, 出力を応 答加速度等として多自由度法によるモード解析【汎用モード解析ソ フト ME' scope】により, 固有振動数, 減衰定数, モード形を求め た。なお, 減衰定数については, 得られた周波数応答関数に基づき カーブフィット法により算出した。

\section{3 人間荷重の影響を調べるための実験}

根太床組に人間荷重を積載した場合の固有振動数と減衰定数に及 ぼす影響を調べる実験である。実験は, 基本振動特性実験の場合と 同様の加振・測定・振動特性の算出方法であるが, 人間荷重の影響 を調べるために, 床の固定荷重だけの場合と鍾による積載荷重を分 散的に付加した場合について, 人間 10 人 (人間の合計質量 $723.5 \mathrm{~kg}$ ) を分散的に積載した状態(図 5(2)〜 (5)及び7)参照)について行うこと とした。なお, 人間の姿勢が減衰に及ぼす影響を調べるために, 直 立姿勢, 中腰前傾姿勢, 体育座り姿勢, 足伸ばし後支え姿勢の 4 姿 勢 (写真 2 参照) について実験を行うこととした。

\section{4. 有限要素法モデル}

有限要素法解析については, 汎用有限要素法解析ソフト $\left[\mathrm{NX}_{-}\right.$ Nastran]を用い, 図 7 に示すように, 床根太材・床下張り材ともに 板要素（曲げ・せん断を考慮）とし，ビスによる接合部としては 3 方向バネ要素とした解析モデルを用いた。床根太のヤング係数は各 床根太材毎に行った曲げ実験による実測值, 構造用合板のヤング係 数については曲げ実験による実測值の平均值とし, ポアソン比は一 律に 0.4 としている。バネ要素の剛性は, せん断実験值と文献 ${ }^{18)}$ 参考に CN65 釘相当ビス接合部 $550 \mathrm{~N} / \mathrm{mm}, \mathrm{CN} 90$ 釷相当ビス接合部 $800 \mathrm{~N} / \mathrm{mm}$ としている（母材の繊維方向に対するせん断方向の影響は なく, 引き抜き剛性はせん断剛性と同じと仮定。なお, 各ば龵定数 を 10 倍として解析しても得られる固有振動数等は変化しないこと を確認しており, 採用したば衫定数の值は解析上便宜的に決定した ともいえる)。各要素の大きさは接合部位置で区切ることとしたが, 解析モデルの全体像は図 8 に示した通りである。この場合, 支持点 は各床根太が単純支持されたものとし, 支点間距離(スパン)は頭つ なぎ材間の内法寸法としている。

\section{5. 実験結果とその考察}

\section{1 ッーウェイ・アクション効果}

図 9(a)(b)には, [1]横一線分布荷重載荷時及び[2]縦一線分布荷重載 荷時の各根太中央の鉛直変位が, それぞれ示してある。また, 同図 には, 有限要素法解析による変位も併せて示してある。

同図より, [1]横一線分布荷重載荷の場合には各根太の変位には大 きな差違はなく（両端の根太への作用荷重が少ないことにより, 変

(5) (4) (3) (2) (1) 0 (1)' (2)' (3)' (4)' (5)'

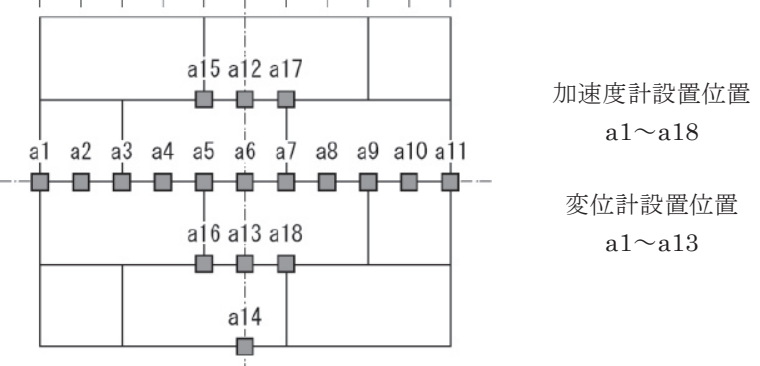

図 6 加速度·変位の測定位置

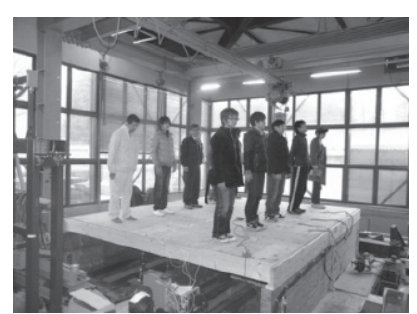

直立姿勢 [表 3(2)に対応]

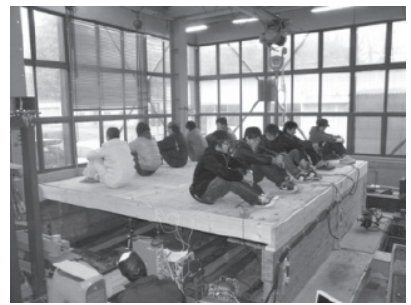

体育座り姿勢［表 3(4)対応]

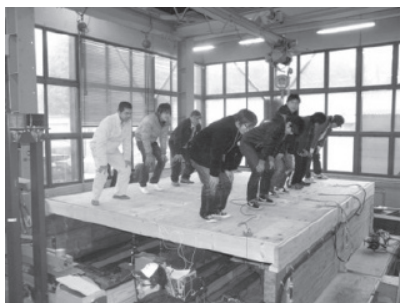

中腰前傾姿勢 [表 3(3)に対応]



足伸し後支え姿勢 [表 3(5)対応]

写真 2 人間 $(10$ 人)の姿勢

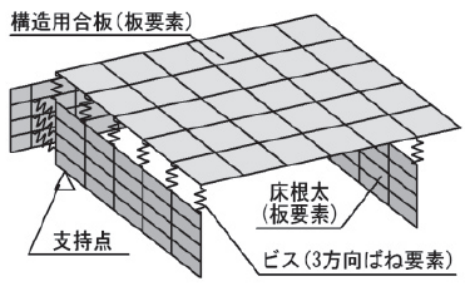

板要素:(ポアソン比 0.4) 床根太

$\mathrm{E}=9.07 \sim 10.49 \mathrm{kN} / \mathrm{mm}^{2}$ 合板 $\mathrm{E}=9.10 \mathrm{kN} / \mathrm{mm}^{2}$ (平均)

ビス接合部の剛性:

$\mathrm{CN} 90$ 相当ビス $800 \mathrm{~N} / \mathrm{mm}$ $\mathrm{CN} 65$ 相当ビス $550 \mathrm{~N} / \mathrm{mm}$

図 7 解析モデルの各要素の諸元

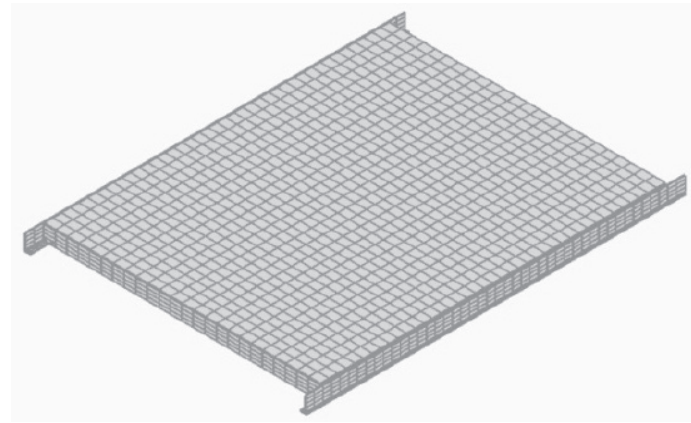

図 8 解析モデル全体像

位も小さい），ツーウェイ・アクション効果は無いように見える。 [2]縦一線集中荷重載荷の場合には載荷された床根太の両側に隣接 した 2 本の床根太の変位が大きく, 3 番目以遠の床根太の変位はほ とんどないことがわかる。根太 0 位置に載荷した場合の，各根太の 鉛直変位と曲げ剛性に基づいて各根太が負担している荷重を算定す ると, 載荷位置の床根太 0 が約 $40 \%$ の荷重を負担し, 隣接する床根 太（1)と (1)') が 2 本合計で約 $40 \%$, 再隣接する床根太 (2)と (2)') が 2 本合計で約 $17 \%$, これら以外の床根太合計で約 3\%となる。こ 


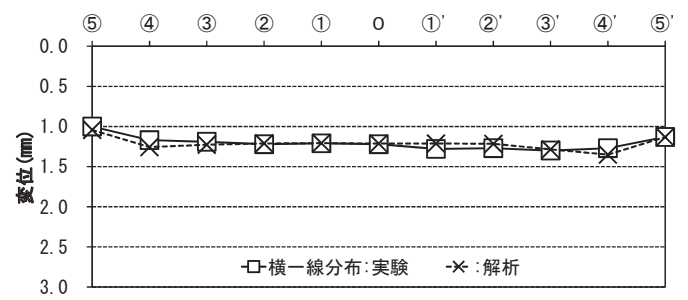

(a)横一線分布荷重載荷時の各根太スパン中央部の変位

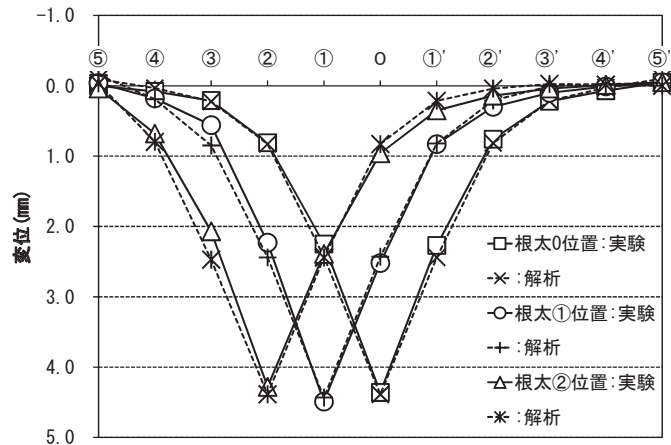

(b)縦一線分布荷重載荷時の各床根太スパン中央部の変位

図 9 静的鉛直載荷時の床根太変位

のことから，試験対象の床根太の床下張りによるツーウェイ・アク ション効果は, 荷重の約 $60 \%$ を隣接する床根太類に伝達する効果が あることがわかるが, 特に両隣接する 2 本の床根太(幅でいえば片側 $910 \mathrm{~mm}$, 両側合計 $1800 \mathrm{~mm}$ )までの伝達効果が高いといえよう。

また，同図より，有限要素法解析による結果は実験值と良く一致 していると見てよく，適切なモデルを選択すれば，根太床のツーウ エイ・アクション効果を評価する手法として採用した解析モデルに よる有限要素法解析は有効であることを示唆している。

\section{2 基本的な振動特性}

図 10 には,床の固定荷重だけの場合と物品荷重を分散的に付加し た場合の実験により得られた周波数応答関数が示してある。また, 表 3 には, 実験により得られた固有振動数と減衰定数の結果と解析 值が一括表示してある。

（1）人間荷重を載荷しない状態の振動特性

表 3 より，人間荷重の無い状態における根太床の基本的な振動特 性について次のことがいえよう。

表 3 中(1)固定荷重だけの場合の 1 次固有振動数は実験 $19.2 \mathrm{~Hz}$ ・解 析 $19.4 \mathrm{~Hz}$ (「解析值 $/$ 実験值」 $=1.01$ ), 2 次固有振動数は実験 $25.8 \mathrm{~Hz}$ • 解析 $22.1 \mathrm{~Hz}$ (同比 $=0.86), 3$ 次固有振動数は実験 $33.7 \mathrm{~Hz}$ ・解析 $29.1 \mathrm{~Hz}$

（同比 $=0.86 ）$ であり, 解析值は 1 次固有振動数については実験值 を精度良く予測するといえるが, 高次振動数については $15 \%$ 程度低 く予測することになる。

図 11 には，実験及び解析から得られた 1 3 次固有振動数に対応 する振動モードが示してあるが，両者のモード形は類似した形とな っており，解析の有効性を示しているといえよう。

次に, 物品荷重を付加した場合についてみれば（表 3 中66参照）, 1 次固有振動数は実験 $10.1 \mathrm{~Hz}$ ・解析 $12.5 \mathrm{~Hz}$ (「解析值／実験值」= $1.24), 2$ 次固有振動数は実験 $14.1 \mathrm{~Hz}$-解析 $14.0 \mathrm{~Hz}$ (同比 $=0.99), 3$ 次固有振動数は実験 $17.2 \mathrm{~Hz}$ ・解析 $18.5 \mathrm{~Hz}$ (同比 $=1.08$ ) で, 1 次固 有振動数についての解析精度は(1)固定荷重のみの場合に比べると低 下寸るが，この原因としては分散配置された錘のモデル化の影響が

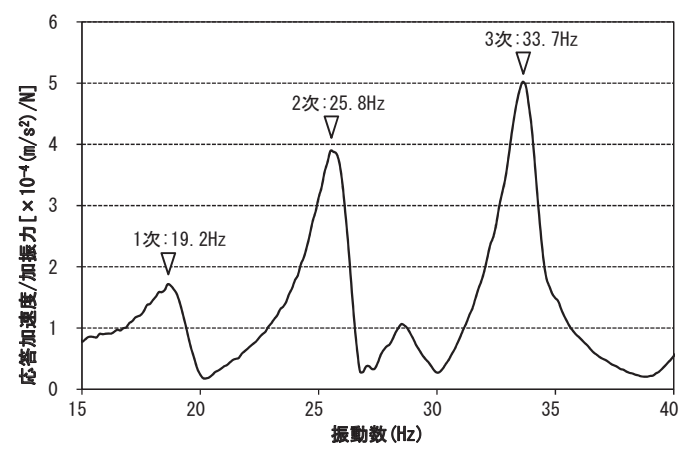

図 10 周波数応答関数の例【(1)固定荷重の夕】

表 3 インパクトハンマー加振実験の結果一覧表【( )内は解析值】

\begin{tabular}{|c|c|c|c|c|c|c|c|}
\hline \multirow[b]{2}{*}{$\begin{array}{l}\text { 番 } \\
\text { 号 }\end{array}$} & \multirow[b]{2}{*}{ 荷重条件 } & \multicolumn{2}{|c|}{1 次 } & \multicolumn{2}{|c|}{2 次 } & \multicolumn{2}{|c|}{3 次 } \\
\hline & & $\begin{array}{c}\text { 振動数 } \\
(\mathrm{Hz})\end{array}$ & $\begin{array}{c}\text { 減衰 } \\
\text { 定数 } \\
(\%)\end{array}$ & $\begin{array}{c}\text { 振動数 } \\
(\mathrm{Hz})\end{array}$ & $\begin{array}{c}\text { 減衰 } \\
\text { 定数 } \\
(\%)\end{array}$ & $\begin{array}{c}\text { 振動数 } \\
(\mathrm{Hz})\end{array}$ & $\begin{array}{c}\text { 減衰 } \\
\text { 定数 } \\
(\%)\end{array}$ \\
\hline (1) & 固定荷重のみ & $\begin{array}{r}19.2 \\
(19.4) \\
\end{array}$ & 3.3 & $\begin{array}{r}25.8 \\
(22.1) \\
\end{array}$ & 2.7 & $\begin{array}{r}33.7 \\
(29.1) \\
\end{array}$ & 2.3 \\
\hline (2) & $\begin{array}{l}\text { 直立 } \\
(10 \text { 人) }\end{array}$ & 21.8 & 10.6 & 29.8 & 6.9 & 35.3 & 6.7 \\
\hline (3) & $\begin{array}{l}\text { 中腰前傾 } \\
(10 \text { 人) }\end{array}$ & 19.4 & 6.1 & 26.2 & 4.8 & 33.3 & 4.3 \\
\hline (4) & $\begin{array}{l}\text { 体育座り } \\
(10 \text { 人) }\end{array}$ & 18.6 & 14.4 & 26.8 & 8.9 & 33.9 & 7.1 \\
\hline (5) & $\begin{array}{l}\text { 足伸し後支え } \\
(10 \text { 人) }\end{array}$ & 19.4 & 20.5 & 25.3 & 12.9 & 33.9 & 5.3 \\
\hline (6) & (1)十物品荷重 & $\begin{array}{r}10.1 \\
(12.5) \\
\end{array}$ & 4.9 & $\begin{array}{r}14.1 \\
(14.0) \\
\end{array}$ & 2.6 & $\begin{array}{r}17.2 \\
(18.5) \\
\end{array}$ & 3.7 \\
\hline (7) & $\begin{array}{l}\text { (1)十物品荷重 } \\
+ \text { +直立 }(10 \text { 人) }\end{array}$ & 10.4 & 7.3 & 14.7 & 10.0 & 18.7 & 3.1 \\
\hline
\end{tabular}

1 次モード 実験 $\quad 19.2 \mathrm{~Hz}$

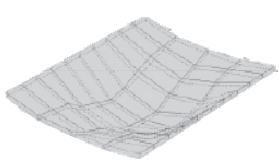

解析

$19.4 \mathrm{~Hz}$

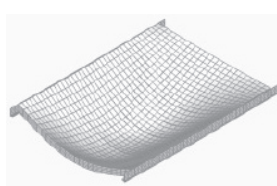

$22.1 \mathrm{~Hz}$

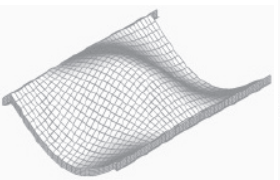

$29.1 \mathrm{~Hz}$

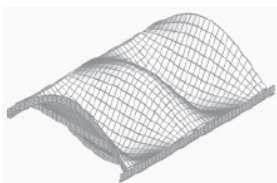

図 11 振動モード形の例【(1)固定荷重のみ】

考えられる。

人間荷重が無い場合の減衰定数は, 1〜3 次固有振動数で 2.3〜 $4.9 \%$ であり，固定及び物品荷重載荷時（人間荷重の無い場合）の減 衰は大きくないといえよう。

（2）根太床の 1 次固有振動数の概算

根太床の 1 次固有振動数を，有限要素法等の手法を用いずに簡便 に予測できれば，構造設計を行う上で有用である。「5.1 ツーウェ イ・アクション効果」で検討したように、【1】横一線分布荷重載荷 の場合にはツーウェイ・アクション効果は無いように見え, 1 次固 有振動数に対応する 1 次モード形を大観すればスパン方向の 1 方向 振動が卓越しているとみることができよう。このことは, 荷重(質量) が等分布的に存在する場合には，根太床全体をスパン方向に架け渡 された 1 本の梁として捉えることができることを予感させる。そこ 
で, 根太床に梁の振動理論を適用して, 1 次固有振動数を算定して みることとする。連続梁の固有振動数は次式で与えられる。

$$
\begin{array}{r}
f=\frac{\pi}{2 l^{2}} \sqrt{\frac{E I}{\mathrm{w}}} \\
\text { ここに, } \quad f: 1 \text { 次固有振動数 } \quad(\mathrm{Hz}) \\
E I: \text { 曲壮剛性 }\left(\mathrm{N} \cdot \mathrm{m}^{2}\right) \\
W: \text { 質量 } \quad(\mathrm{kg} / \mathrm{m})
\end{array}
$$

上式に, 根太床の固定荷重のみの場合(表 3(1)に対応)の諸元を代入 すれば, 1 次振動数は次のように計算される。

$$
f=\frac{\pi}{2 l^{2}} \sqrt{\frac{\sum(E I)}{\sum(w)}}=\frac{3.14}{2 \times 3.64^{2}} \sqrt{\frac{1.92 \times 10^{5} \times 11}{319 / 3.64}}=18.4(\mathrm{~Hz})
$$

計算值 $18.4 \mathrm{~Hz}$ と実験值 $19.2 \mathrm{~Hz}$ とを比較すればその比は 0.96 で, 両者は概称一致しているとみてよく,この結果は上述の洞察を裏付 けるものと判断してよかろう(ただし, 供試体は本実加工合板である ので, コンポジット効果は大きくないことに留意しておく必要があ ろう)。

同様に, 分散的に物品荷重を載荷した場合(表 36に対応)について 計算すれば，次のようになる。

$$
f=\frac{\pi}{2 l^{2}} \sqrt{\frac{\sum(E I)}{\sum(w)}}=\frac{3.14}{2 \times 3.64^{2}} \sqrt{\frac{1.92 \times 10^{5} \times 11}{(319+513) / 3.64}}=11.4(\mathrm{~Hz})
$$

計算值 $11.4 \mathrm{~Hz}$ と実験值 $10.1 \mathrm{~Hz}$ とを比較すればその比は 1.13 で, 計算值の方が $15 \%$ 程度大きい結果となるが, 実用上問題がないと考 えて大過なからう。

以上のことは, スパン $3.6 \mathrm{~m} ・$ 幅 $4.55 \mathrm{~m}$ の 2 辺支持された根太床で 確認されたものであり, スパン・幅・支持条件が異なる場合につい ては更なる検討が必要であるが, 荷重が等分布的に載荷されて 2 辺 支持された状態の根太床の 1 次固有振動数を概算的に予測する手法 の可能性が示されたといえよう。

\section{3 固有振動数に及ぼす人間荷重の影響}

固有振動数に及ぼす人間荷重の影響について, 表 3 に示寸実験結 果一覧表に基づけば，次のことがいえよう。

固有振動数について, (1)固定荷重だけの場合【総質量 $319 \mathrm{~kg} 】 と$ (2)物品荷重が無く固定荷重と人間荷重（分散載荷）が載荷された場 合【総質量 $1042.5 \mathrm{~kg}(=319+723.5)$ 】の固有振動数を比較すれば（1) に対する(2)の質量は 3.29 倍), 1 次固有振動数では(1) $19.2 \mathrm{~Hz}$ と (2) $21.8 \mathrm{~Hz}$ [(2) / (1) $=1.14], 2$ 次固有振動数では(1) $25.8 \mathrm{~Hz}$ と (2) $29.8 \mathrm{~Hz}$ $[(2) /(1)=1.16], 3$ 次固有振動数では(1) $33.7 \mathrm{~Hz}$ と (2) $35.3 \mathrm{~Hz}$ [(2) / (1) =1.05]である。同様に, (6)物品荷重載荷の場合【総質量 $832 \mathrm{~kg}(=319$ $+513)$ 】 (7)それに人間荷重を付加した場合【総質量 $1555.5 \mathrm{~kg}$ $(=319+513+723.5)$ 】とを比較すれば（6)に対する(7)の質量は 1.90 倍), 1 次固有振動数では(6) $10.1 \mathrm{~Hz}$ と (7) $10.4 \mathrm{~Hz}[(7 /$ /6) = 1.03], 2 次 固有振動数では(6) $14.1 \mathrm{~Hz}$ と (7) $14.7 \mathrm{~Hz}[$ [7/ (6)=1.04], 3 次固有振動 数では(6) $17.2 \mathrm{~Hz}$ と (7) $18.7 \mathrm{~Hz}[(7 /$ (6)=1.09] である。人間荷重が付 加された場合, 固有振動数が若干大きくなる傾向（全重量に対して 人間荷重の占める割合が多い固定荷重のみの場合(2)の方が顕著) が 見られる。

いずれにしても, 人間荷重が載荷され計算上の質量が 1.9〜3.3 倍

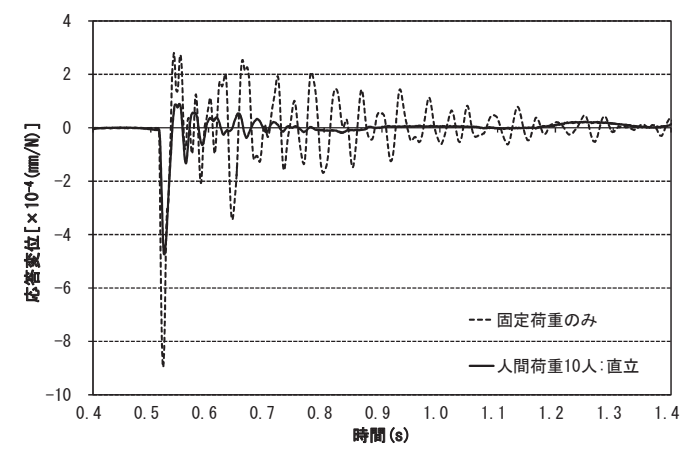

図 12 応答変位波形の例

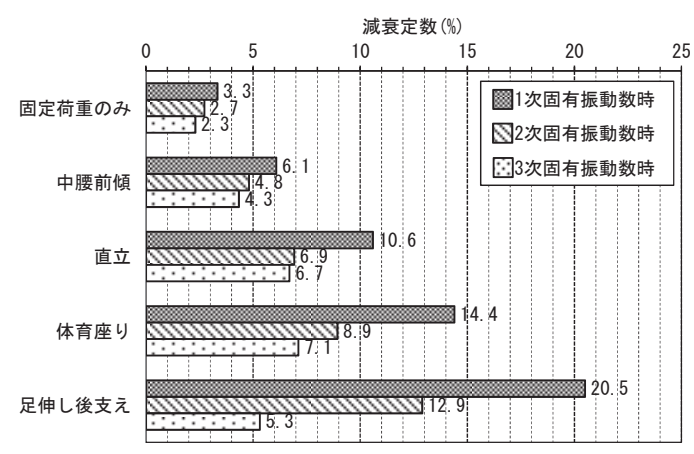

図 13 人間の姿勢と減衰定数との関係

となっても, 固有振動数は $15 \%$ 程度しか変化しない（かつ, 大きく なる）ことを考えれば，床根太の固有振動数に及ぼす人間荷重の影 響は小さく, 根太床の固有振動数を考える上では, 人間荷重を無視 しても大過ないといえよう。この物理学の一般常識に反するように 見える現象については, 既報 ${ }^{3)}$ の梁床の場合において, 人間と床と の相互作用による位相ずれによって生じることを明らかにされてい るが，根太床の場合にもこの現象が確認されたと言ってよからう。

\section{4 人間の姿勢が固有振動数と減衰定数に及ぼす影響}

(1) 人間の姿勢が固有振動数に及ぼす影響

物品荷重の無い状態で人間 10 人が分散載荷された場合の固有振 動数は（表 3 中(2)〜 (5)参照), 姿勢に関わらず, 1 次固有振動数 18.6 $\sim 22.7 \mathrm{~Hz}, 2$ 次 $25.3 \sim 30.0 \mathrm{~Hz}, 3$ 次 $33.3 \sim 37.8 \mathrm{~Hz}$ であり, (1)固定荷 重のみの場合（1 次 $19.2 \mathrm{~Hz}, 2$ 次 $25.8 \mathrm{~Hz}, 3$ 次 $33.7 \mathrm{~Hz}$ ）とほぼ同じ か若干大きい。また, 物品荷重がある状態で人間 10 人が直立姿勢で 分散載荷された場合も (表 3 中(6) と（7)参照), 同様の傾向がある。こ のことから, 人間の姿勢は根太床の固有振動数に影響しないとみて よかろう。

(2) 人間の姿勢が減衰定数に及ぼす影響

図 12 には, (1)固定荷重のみの場合と (2)人間荷重載荷の場合（10 人分散載荷・直立，全荷重に占める人間荷重の割合は 69\%）の床組 中央部の応答変位波形が例示してある。同図より, 人間荷重載荷の 場合には変位波形が急速に減衰することがわかる。

図 13 は, 表 311) (5)に基づき, 人間 10 人が載荷位置において 4 種類の姿勢をとった場合の, 各固有振動数に対応寸る減衰定数の值 を図示したものである。同図表より, 1 次固有振動数に対応寸る減 衰定数は, (1)固定荷重のみの減衰定数 $3.3 \%$ 最も小さく, (3)中腰前 傾姿勢 $6.1 \%$, (2)直立姿勢 10.5\%, (4)体育座り姿勢 $14.4 \%$, (5)足伸 し後支え姿勢 $20.5 \%$ の順に大きく, 人間が床に接触する面積が大き いほど減衰が大きくなる傾向があるといえよう。 
1 次固有振動数に対応する減数定数に及ぼす姿勢の影響を調べる ために, 固定荷重のみの減衰定数 3.3\%を差し引けば, 中腰前傾姿勢 $2.8 \%(=6.1-3.3)$, 直立姿勢 7.2\% (=10.5 - 3.3), 体育座り姿勢 $11.1 \%$ $(=14.4$ - 3.3) , 足伸し後支え姿勢 $17.2 \%(=20.5$ - 3.3) であり [直立 姿勢を基準とすれば $0.38 \sim 2.36$ 倍の差がある], 減衰定数に及ぼす 人間の姿勢の影響が大きいことがわかる。一方， 2 次固有振動数に ついては, 中腰前傾姿勢 $2.1 \%(=4.8-2.7)$, 直立姿勢 $4.2 \%(=6.9-2.7)$, 体育座り姿勢 $6.2 \%(=8.9-2.7)$, 足伸し後支え姿勢 $10.2 \%(=12.9-2.7)$ であり [直立姿勢の $0.50 \sim 2.43$ 倍], 3 次固有振動数については, 中 腰前傾姿勢 $2.0 \%(=4.3-2.3)$, 直立姿勢 $4.4 \%(=6.7-2.3)$, 体育座 り姿勢 $4.8 \%(=7.1-2.3)$, 足伸し後支え姿勢 $3.0 \%(=5.3-2.3)$ であ る [直立姿勢の $0.45 \sim 1.09$ 倍］ことがわかる。以上のことから, 高 次振動数に対応する減衰定数に及ぼす人間の姿勢の影響は, 1 次固 有振動数に対応する減衰定数の場合ほど大きくないといえよう。

\section{6. まとめ}

スパン $3.64 \mathrm{~m} ・$ 幅 $4.55 \mathrm{~m}$ の 2 辺支持された床根太の鉛直振動特性 に関して, 本報の実験により明らかになったことをまとめれば，次 のようになろう。

(1) 試験対象床根太のツーウェイ・アクション効果は, 隣接する 2 本の床根太(幅でいえば $910 \mathrm{~mm}$ )まで波及し, 荷重の $60 \%$ は隣接する 床根太が負担する効果を有する。また，本論文で採用した解析モデ ルを用いた有限要素法解析は, 根太床のツーウェイ・アクション効 果および固有振動数・モード形を評価する手法として有効である。

（2）荷重が等分布的に載荷され 2 辺支持された根太床の 1 次固有振 動数を概算的に予測する手法として, 根太床全体をスパン方向に架 け渡された梁として捉え, 梁の振動理論により固有振動数を算定す る方法の可能性が示された。

（3）根太床の固有振動数を算定する上では, 人間荷重の影響は少な

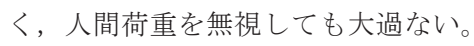

（4）人間の姿勢が 1 次固有振動数に対応する減衰定数に及ぼす影響 は, 中腰前傾姿勢, 直立姿勢, 体育座り姿勢, 足伸し後支え姿勢の 順に大きく, 人間が床と接触する面積が大きいほど大きくなる傾向 があるが，高次固有振動数に対応する減衰定数に及ぼす影響はそれ ほど大きくない。

\section{謝辞}

木造根太床の振動特性に関する一連の実験実施に当たり，本村明 日香氏 (スウェーデンハウス) 並びに各実験当時に卒業研究生として 在籍した塚本良子, 住田悟, 田中博昭, 前田雄一の各氏より多大な る御助力を得た。ここに記して感謝の意を表します。

\section{参考文献}

1）日本建築学会 : 木質構造設計規準 - 同解説 - 許容応力度 - 許容耐力設計法 -, 2002. 10

2）鈴木秀三・藤野栄一・野口弘行 : 木造床の振動特性に及ぼす人間荷重の影 響に関する実験的研究 (第 1 報), 日本建築学会構造系論文集第 585 号, pp. 123-129, 2004. 11

3）藤野栄一, 鈴木秀三, 野口弘行：同上 (第 2 報), 日本建築学会構造系 論文集第 589 号, pp. 127-142，2005. 3

4) 藤野栄一, 鈴木秀三, 野口弘行 : 衝撃加振力を受ける木造梁床モデルの鉛直
振動応答に関する研究, 日本建築学会構造系論文集第 591 号, pp. 107-112, 2005.5

5）鈴木秀三, 藤野栄一, 野口弘行, 五十田博 : 木質ハイブリッド梁床モデルの 鉛直振動特性に関する実験的研究, 日本建築学会構造系論文集第 596 号, pp. $65-70,2005.10$

6）本村明日香, 藤野栄一, 塚本良子, 鈴木秀三: 根太床の鉛直振動性状に及ぼ すコンポジットアクションの影響に関する実験的研究, 日本建築学会大会学 術講演梗概集 C-1, pp. 53-54, 2005. 9

7）塚本良子, 藤野栄一, 本村明日香, 鈴木秀三 : 根太床の動的挙動に及ぼすツ 一ウェイ・アクション効果に関する実験的研究（その 1 : 静的性状）, 日本 建築学会大会学術講演梗概集 C-1, pp. 55-56, 2005.9

8）藤野栄一, 塚本良子, 本村明日香, 鈴木秀三: 同上 (その 2 : 動的性状), 日本建築学会大会学術講演梗概集 C-1，pp. 57-58, 2005.9

9）鈴木秀三, 藤野栄一, 園田明日香:根太床のツーウェイ・アクション効果に 関する解析的研究, 日本建築学会大会学術講演梗概集 C-1, pp. 33-34, 2007.9 10）鈴木秀三, 井原行孝, 藤野栄一：根太床の振動特性と人間荷重の減衰性に 及ぼす影響に関する研究 (その 1), 日本建築学会大会学術講演梗概集 C-1, pp. 439-440, 2010.9

11）井原行孝, 鈴木秀三, 藤野栄一：同 上 (その 2), 日本建築学会大会学術 講演梗概集 C-1，pp. 441-442，2010.9

12）鈴木秀三, 井原行孝, 藤野栄一 : 有開口木造根太床の鉛直振動特性と有限 要素法の適用性, 日本建築学会大会学術講演梗概集 C-1, pp. 565-566, 2011.8 13）井原行孝, 鈴木秀三, 藤野栄一 : 衝撃加振力を受ける木造根太床の鉛直振 動応答に関する研究, 日本建築学会大会学術講演梗概集 C-1, pp. 567-568, 2011.8

14）竹山謙三郎 - 久田俊彦 : 木造床組の振動障碍に就いて, 建築學會論文集 第 33 号, pp. 9-10, 1944. 4

15）安藤直人・杉山英男：木造床の振動性状（第 3 報），ストレス・スキン・ パネルの衝撃荷重による動たわみと歩行振動, 日本木材学会木材学会誌, Vol. 31, No. 2, pp. 97-102, 1985

16）小野英哲・横山裕 : 人間の動作により発生する床振動の振動感覚上の表 示方法に関する研究一振動発生者と授振者が同じ場合一, 日本建築学会構造 系論文集，第 381 号，pp. 1-9，1987.11

17）中村昇 - 野地清美 - 西山豊 - 伊野部健吉 - 安藤直人 : 木造床の振動性状 と感覚評価, 日本木材学会木材学会誌, Vol.49, No. 2, pp. 78-83, 2003

18） 2007 年枠組壁工法建築物構造計算指針，社団法人日本ツーバイフォー建 築協会発行

（2011年 9 月27日原稿受理，2012年 3 月 8 日採用決定） 